3. Бондаренко А. I. Художній дискурс в інтерпретаційному вимірі: лінгвостилістичний аспект. Ніжин, 2008. 226 с.

4. Бурбело В. Б. Художній дискурс в історії французької мови та літератури: автореф. дис. на здобуття наук: спец. ступеня доктора філол. наук: 10.02.05 / Київ,1999. 42 с.

5. Вецкур Т. А. Текст та дискурс: проблеми диференціації. Актуальні проблеми філологї та перекладознавства. Хмельницький, $2005.73 \mathrm{c}$.

6. Демьянков В. Текст и дискурс как термины и как слова обыденного язика: підручник. Запоріжжя: Прем’єр, 2008. 332 с. - Режим доступу http://www.infolex.ru

7. Приходько А. М. Концепти і концептосистеми в когнітивнодискурсивній парадигмі лінгвістики, Запоріжжя. 2008. 332 с.

8. Шевченко I. С. Когнітивно-комунікативна парадигма i аналіз дискурсу. Дискурс як когнітивно- комунікативний феномен. Харків, 2005. C. 9-20.

DOI https://doi.org/10.30525/978-9934-588-90-7-17

\title{
ПРОБЛЕМА ЕВОЛЮЦЇ̈ ПАТРІОТА В КОНТЕКСТІ ВІЙНИ НА СХОДІ УКРАЇНИ (НА МАТЕРІАЛІ РОМАНІВ С. ЖАДАНА «ВОРОШИЛОВОГРАД» ТА «ІНТЕРНАТ»)
}

Волосянко I. В. аспірантка

Прикарпатський національний університет імені Василя Стефаника, викладачка кафедри перекладу та філології

Приватний вищий навчальний заклад Університет Короля Данила м. Івано-Франківськ, Украӥна

Тема війни вже неодноразово була центром зацікавлень та досліджень як науковців, так і письменників. Саме у процесі еволюції і становлення людство віками тягнуло за собою шлейф міжусобиць, а митці за допомогою метафорики, сюжетних колізій у рефлексивній формі відтворювали ті чи інші події. Незважаючи на те, що війна, здавалося б, мала залишитися в минулому, у своїй сув'язі зі смертю та деструкцією вона повернулася сьогодні в реальне життя людей, а, відповідно, й на сторінки художньої літератури. 
3 початком російсько-української війни на Сході України уже в другому десятиріччі XXI ст. в сучасній українській прозі проблема людини і війни постала знову. I якщо роман «Ворошиловоград» Сергія Жадана лише викривально окреслював ледь проявлені, але все-таки вже зримі причини надто легковажного ставлення донеччан і луганців до створення Новоросії та підпорядкування цих питомо українських територій Росії, то вже в романі «Інтернат», автор ставить гостро питання «мирна людина - i війна», «дитина - i війна», а сам твір $\epsilon$ яскравим зразком антимілітарної прози.

Роман Сергія Жадана «Ворошиловоград» про Луганщину. Він має доволі промовисту присвяту: «Історї украӥнського рейдерства присвячується»[4]. Жанр цього твору дискусивний. Літературознавець Валентин Бушанський зазначає, що «Сергій Жадан написав книгу, жанр якої визначити неможливо» [2, с. 1]. Він стверджує, що «Ворошиловоград» - «достеменна поема» [2, с. 1], але таки робить висновок, що цей твір - «справжній чоловічий роман» [2, с. 3]. А поет Лесь Белей називає літературним методом цього твору «химерний соцреалізм»[1, с.1]. Водночас засилля нецензурної лексики, опис безвідповідальних любовних походеньок персонажів і їхньої чорної депресії, замішаний на жовчному сарказмі, однозначно впевнює, що роман «Ворошиловоград» - явище літературного постмодерну. У красному письменстві постмодернізм зазвичай проявляється через притаманний йому скепсис, іронію щодо проголошуваних модернізмом універсальних істин, якими є об'єктивна реальність, мораль, правда, людська природа, розум, мова та соціальний прогрес.

Назвою роману послужило найменування міста Луганськ, який 3 усією прилеглою територією на сторінках твору ніби застряг у «позачассі»: ця територія нічийна, якщо не брати до уваги сучасного майже махновця Владлена Марленовича чи то Марлена Владленовича, нувориша-скоробагатька, якому потрібне все, що має хоч якусь вартість: чужі бензозаправки, старий аеродром, земля під безмежні кукурузні плантації. Цей олігарх їздить по залізниці власним фешенебельним поїздом, як новоявлений князьок, а навкруги відбуваються кінцесвітні речі: степами кочують монголи й цигани, юні дівчатка мріють стати повіями, як це робить одна з героїнь Катя. Фермери бездумно нищать $\mathrm{i}$ отруюють родючу землю й готові проливати людську кров. Рекет породжує рекет. Урешті, вбивати готові всі, й таки вбивають на кожному кроці. Повна анархія, відсутність дії законів, байдужість держави до людей - це якраз те, що породило в населення бажання «твердої руки» Путіна та бодай якоїсь стабільності. 
Роман «Ворошиловоград» мав широкий розголос відразу ж після написання, хоч російсько-українська війна тоді ще була у майбутньому i став не тільки «Книгою року», але, пізніше, і «Книгою десятиліття», отримав швейцарську літпремію «Jan Michalski Prize». Його переклали російською, польською, угорською, німецькою, англійською, французькою мовами. На основі роману було знято фільм з унікально вдалою назвою - «Дике поле».

Причиною написання роману «Інтернат» Сергія Жадана став початок війни на Сході України. У 2014 році цьому письменникові надсилав листи чоловік 3-під Луганська зі щоденниковими записами про події на Сході. Саме ці записи стали основою для написання нового твору. Проте герой роману «Інтернат» - Паша - вигаданий повністю, як і племінник цього персонажа, який, незважаючи на свій юний вік, більш свідомий за дядька. Серед героїв твору - безхарактерна сестра Паші та майже розчавлений депресією старий батько головного героя. В анотації до цього твору є такі слова: «....Одного разу, прокинувшись, ти бачиш, за вікном вогонь. Ти його не розпалював. Але гасити його доведеться тобі...Січень 2015 року. Донбас. Пама, вчитель однією зі шкіл, спостерігає, як лінія фронту неухильно наближається до його дому. Стається так, що він змушений ию лінію перетнути. Щоби потім повернутись назад. I для цього йому щонайменше потрібно визначитись, на чиєму боиі його дім...» [5 ].

Смерть у романі чигає на людей на кожному кроці. Щоби виконати прохання дідуся й привезти додому з інтернату малого Сашка, Павло повинен наражатися на страшну небезпеку. А тим часом, читачів дивує Павлова безхарактерність, аполітичність, обурює поведінка Сашкової матері, яка всього лише через єдиний нервовий припадок власного сина вирішила, що іiі дитя - приречений епілептик. Саме через це вона бездумно й жорстоко віддала Сашка в інтернат, незважаючи на те, що це єдиний iii син i що в дитини нема батька, який міг би взяти відповідальність за нього на себе.

Образ типового для Донбасу сільського вчителя Павла у романі Сергія Жадана «Інтернат» показаний в еволюції: від аполітичного, маргінального, байдужого до подій у державі фізичного каліки (про інвалідність учителя ми дізнаємось аж наприкінці твору), до духовно зрілого, яскраво вираженого психотипу свідомого українця. Взагалі, чоловічі образи в цьому романі суттєво програють образам жінок, які все-таки здатні на вчинки. Особливої уваги заслуговує директорка інтернату, яка не дозволила місцевим сепаратистам зірвати з будівлі цього навчально-виховного закладу український жовто-синій прапор. Ї̈̈ i 
в рідному інтернаті, й у найближчому населеному пункті знають на прізвисько Спортсменка, бо вона колись сама жила та вчилася в цьому інтернаті. 3 усього взуття і влітку, й взимку вона мала тільки гумовополотняні кеди, в яких змушена була ходити упродовж року. Така промовиста художня деталь із минулого літературної героїні потужно розкриває її образ, пояснює громадянську позицію Спортсменки досить влучно й вмотивовано. Тільки сильні духом люди, загартовані життєвими труднощами в екстремальних та небезпечних для життя ситуаціях, навіть не обирають компроміс із власною совістю. На війні не можна бути байдужим. Кожен мусить себе ідентифікувати, визначитись, на якому він боці: «....давно вже слід було визначитися, з якого ви боку. Звикли все життя ховатися. Звикли, що ви ні при чому, що за вас завжди хтось усе вирішить, що хтось усе порішає. Не цьього разу. Тому щзо ви теж усе бачили й усе знали. Але мовчали й не говорили. Судити вас за ие, звісно, не будуть, але й на вдячну пам'ять нащадків можете не розраховувати» $[5$, с. 160$]$.

Одіссея головного героя роману Павла в інтернат і назад додому страшна, з багатьма пригодами й суцільним ризиком для життя. Проте ця мандрівка примушує колишнього байдужого до політичного життя в країні вчителя мислити по-новому. Павло прозріває у ставленні до малого Сашка, який виявляється сміливішим від нього й більш свідомим Слабовольний учитель стає активним борцем за власне й племінникове життя, вимагає від інших активних дій.

Подорож Павла, як і подорож Гомерового Одіссея, кільцева, але і Жаданів, і Гомерів герої повертаються додому абсолютно іншими людьми: сильнішими, відважнішими, змужнілими. Образ самого інтернату в цьому творі - символічний. Саме таким жорстоким i непривітним місцем, як інтернат, стає територія, зайнята окупантами.

Сергій Жадан простих людей 3 народу змалював 3 правди, «поживому натуралістично» [1, с. 2], без прикрас та ідеалізацій. Кожен герой твору маркований власним «Я» із притаманними йому страхами та огріхами. Автором художньо цінного, якісного твору, можна вважати того, хто зумів відтворити об'єктивну дійсності, реальність 3 неповторною образною індивідуалізацією. Саме такої майстерності вдалось досягти Сергію Жадану, у своїх дискурсах.

\section{Література:}

1. Белей Л. Химерний соцреалізм Сергія Жадана. Електронний pecypc. Режим доступу: http://itakcent.com/2010/09/27/dvi-recenzijina-voroshylovhrad/ 
2. Бушанський В. Місто мертвих. Електронний ресурс. Режим доступу: https://life.pravda.com.ua/columns/2011/07/1/81107/.

3. Галич О. А. Історія літературознавства : підручник / О. А. Галич. Київ: Либідь, 2013. 392 с.

4. Жадан С. Ворошиловград: роман. Харків: «Фоліо», 2010. 442 с.

5. Жадан С. Інтернат: роман. Чернівці : Меридіан Черновіц, 2017. $336 \mathrm{c}$.

6. Романець В. А. Психологія творчості: Навч. посібник.2-ге вид., доп. Київ: Либідь, 2001. 288 с.

7. Філософія історії: Підручник для вищих шкіл. Харків: Прапор, 2006. 565 c.

DOI https://doi.org/10.30525/978-9934-588-90-7-18

\title{
СОЦІАЛЬНА ТА ПСИХОЛОГІЧНА ДЕТЕРМІНАЦІЯ ЗЛОЧИНУ В ПОВІСТІ «НЕНАВИСТЬ ДО БЛИЖНЬОГО» МИХАЙЛА ГАФІЇ ТРАЙСТИ
}

\author{
Вотьканич М. I. \\ аспірант, \\ викладач кафедри украӥнської літератури \\ Ужггородський національний університет \\ м. Ужгород, Україна
}

Михайло Гафія Трайста - український письменник, що живе та працює в Румунії. Його активна громадська діяльність сприяє активізації культурних контактів України та української меншини Румунії.

Літературна творчість М. Трайсти $є$ гідним продовженням української письменницької традиції на румунських теренах. Прозовий доробок митця розмаїтий за жанрово-стильовими й тематичними векторами.

Нашу увагу, зокрема, привернула перша прозова збірка письменника «Гуцульська душа», що вийшла в Бухаресті у 2008 році. Книгу складають десять оповідань та дві повісті. Події у творах збірки розгортаються переважно в реалістичному ключі, тематично ж їх об'єднує інтерпретація автором кримінальних мотивів. Сюжетотворчою $\epsilon$ ця тема й у повісті «Ненависть до ближнього», що стала об'єктом нашого дослідження. 